\title{
1. The thorny issue of balancing rights
}

\section{THE THORNY ISSUE OF BALANCING RIGHTS: THEORIES AND APPROACHES}

\subsection{What Does 'Balancing Rights' Mean?}

The role of the courts is generally considered to be the resolving of conflicts between rights, and this is indeed their predominant task: deciding which right - and which part - must prevail in each and any of the lawsuits they judge. However, lawsuits are not all alike and some seem to entail a different process, that of balancing rights.

As explained in the Introduction to this book, the idea of balancing goes back to the old times where Justice was depicted as holding a set of scales in her hands. Balancing is considered in this work as the method by which courts 'weigh' conflicting interests and rights in order to find a stable solution; a solution that requires judges to tell which of the rights is the heaviest. ${ }^{1}$

Balancing is central not only to law, but also to life in general. It mirrors what happens in - particularly democratic - societies. ${ }^{2}$ Balancing has been studied in detail by numerous legal scholars from different perspectives, such as philosophy and constitutional law, mainly with regard to Constitutional Courts. ${ }^{3}$ More precisely, scholars have consistently focused on how constitutional courts weigh conflicting rights when

1 Giorgio Pino, Diritti e interpretazione. Il ragionamento giuridico nello Stato costituzionale (Il Mulino 2010) 173. For a critique consider Patrick M McFadden, 'The Balancing Test' [1988] Boston College Law Review 585, $628-632$.

2 Aharon Barak, Proportionality. Constitutional Rights and Their Limitations (CUP 2012) 345-346.

3 The term 'Constitutional Courts' is here applied to courts that have the power to decide on the constitutionality of statutes and laws. Hence, it includes not only the Italian Constitutional Court but both the American and the Canadian Supreme Courts as well. It also includes the European Court of Justice, which can strike down the laws of Member States' if they collide with EU laws and principles. 
they need to decide on the legitimacy of a norm the constitutionality of which has been questioned.

This section provides an overview of the main theories concerning the balancing of rights; it is not intended as an exhaustive illustration of all the existing theories and approaches, ${ }^{4}$ but rather as the presentation of a bird's-eye view of the most influential and recent of these theories; its aims are twofold. First, to demonstrate that the vast majority of scholars have paid only scant attention to the fact that lower courts also balance conflicting rights, often in a similar way to that followed by constitutional courts. ${ }^{5}$ Second, to create a basis for an understanding of the subsequent sections (and chapters), in which the conflict between privacy and copyright will be explained in detail, taking some case studies as examples.

The task of balancing rights belongs both to courts and to the legislator. In setting norms, the legislative power determines what right should prevail in the specific cases where the norm is applicable; the choices made by legislators thus constitute a balance made 'in advance', which is generally applicable to all the possible lawsuits in which the norm will be applied by courts. For their part, the courts also balance rights; however, this does not mean that they become substitutes for the legislative branch. ${ }^{6}$

The cases in which courts balance rights have been grouped by scholars into two main classes, according to whether the rights conflict 'directly' or collide 'indirectly'.' Rights conflict directly when they collide in the absence of a pre-existing 'rule of conflict'; the conflict is indirect when it has already been regulated by law, so that it is possible

4 For a deeper understanding of the phenomenon of balancing I shall make reference to the books and articles cited throughout this section.

5 For instance, Emilio Betti considered the issue of the resolution of conflicts of interest as a key role of any judge: Emilio Betti, Interpretazione della legge e degli atti giuridici (Giuffrè 1949) 18.

6 '[I]n balancing, courts necessarily become legislators and administrators': Alec Stone Sweet, The Judicial Construction of Europe (OUP 2004) 11. Criticism from this point of view comes from T Alexander Aleinikoff, 'Constitutional Law in the Age of Balancing' [1987] Yale Law Journal 943, 984ff; Melvine B Nimmer, 'The Right to Speak From Times to Time: First Amendment Theory applied to Libel and Misapplied to Privacy' [1968] California Law Review 935, 947: 'definitional balancing ... may be criticized as a form of judicial lawmaking, and as such a usurpation of the legislative function'.

7 Pino, Diritti e interpretazione (n 1) 202-203. 
to consider this balancing as a 'second order', or 'meta-balancing', 8 i.e. further balancing, subsequent to that of the legislator.

In the first class of cases two rights enter into direct conflict with one another. In the second class, a right is limited by means of a norm that includes the rules of the conflict; the adoption of that norm is justified as a way of protecting another conflicting right. This means that the first right will need to be balanced not only with the conflicting right, but also with other 'justifications' that support the rule governing the conflict. The clashing rights, in these cases, are therefore not on the same level, since the legislator has already stated that one should cede to the other. ${ }^{9}$

Another possible classification of the conflict between rights considers four situations, which can be either intra- or inter-rights conflicts, involving either total or partial clashes. Intra-rights conflicts are cases where two aspects of the same right, or two scenarios involving that right, clash; inter-rights conflicts are situations where two different rights collide. Clashes can be total or partial: in a total conflict, when one of the two rights prevails, the other must succumb totally. In a partial conflict, on the other hand, a case-by-case approach is still possible, and neither of the two rights must necessarily be totally disregarded. ${ }^{10}$

As the cases analysed here involve informational privacy versus copyright, the conflict is clearly inter-rights; it is also partial, as 'caseby-case regulation' is possible.

The concept and theory of balancing have existed for more than a century. In fact, while courts - especially the US Supreme Court and its German counterpart the Bundesverfassungsgericht - started to rely on the idea and the mechanism of balancing in the mid-twentieth century, scholars had already begun to develop theories of balancing and weighing interests in the early years of the century. ${ }^{11}$ The work of legal

8 Ibid 202.

9 This explanation is that of Pino, ibid 203.

10 Lorenzo Zucca, 'Conflicts of Fundamental Rights as Constitutional Dilemmas' in Eva Brems (ed), Conflicts between Fundamental Rights (Intersentia 2008) 19, 26-27. Riccardo Guastini, 'Teoria e ideologia dell'interpretazione costituzionale' [2006] Giurisprudenza costituzionale 743, 774-775 introduces a similar classification.

11 Barak, Proportionality (n 2) 178ff (consider also the graph at 182 that summarizes how proportionality migrated from Germany to other countries); Jacco Bomhoff, Balancing Constitutional Rights. The Origin and Meaning of Postwar Legal Discourse (CUP 2013) 31ff; Vincent Luizzi, 'Balancing of Interests in Courts' [1980] Jurimetrics 373, 374-376, 380-381; Aleinikoff (n 6) 955-963; McFadden (n 1) 603-611; Alberto Vespaziani, Interpretazioni del bilanciamento dei diritti fondamentali (Cedam 2002); Alec Stone Sweet and Jud 
scholars is also thought to be one of the factors prompting the superior courts to consider, and begin to adopt, this new approach. ${ }^{12}$

In order to enable an understanding of balancing, a primary distinction is habitually made between rules and principles. This distinction is usually attributed to Ronald Dworkin ${ }^{13}$ but probably pre-dates him. ${ }^{14}$ The theorization, which is all but undisputed, ${ }^{15}$ is based on a number of diverse features exhibited by rules and principles. In particular, principles are held to be norms of very high importance on which the entire legal system is based, and which are characterized by vagueness, indeterminacy and high generality; they proclaim the values and state the goals that legislators should pursue. Rules, in contrast, are considered to be linked to specific cases, indicating precise conduct to be followed; they could allow, forbid or oblige a subject to engage in a specific conduct. ${ }^{16}$ Conflicts between rules might be resolved with the classical tool of 'subsumption'17 and/or with the usual criteria of lex posteriori derogat priori and lex specialis derogat legi generali. ${ }^{18}$ While rules could only be applicable to cases, and could not be weighed, principles would instead

Mathews, 'Proportionality Balancing and Global Constitutionalism' [2008] Columbia Journal of Transnational Law 72, 98ff.

12 Aleinikoff (n 6) 952ff recognized three main causes of the US Supreme Court's adoption of the balancing approach: a political, a judicial and an academic imperative.

13 Consider his seminal work: Ronald Dworkin, Taking Rights Seriously (Duckworth 1977).

14 Robert Alexy, A Theory of Constitutional Rights (Julian Rivers tr, OUP 2002) $45 \mathrm{ff}$.

15 Dworkin (n 13) 24ff. See also, with a slightly different approach, Robert Alexy, 'The Construction of Constitutional Rights' [2010] Law \& Ethics of Human Rights 21, and more generally, Alexy, A Theory of Constitutional Rights (n 14) 57ff; Roberto Bin, Diritti e argomenti. Il bilanciamento degli interessi nella giurisprudenza costituzionali (Giuffrè 1992) 9-18. Against the classification of 'rights as principles': Bernhard Schlink, 'Proportionality (1)' in Michel Rosenfeld and András Sajó (eds), The Oxford Handbook of Comparative Constitutional Law (OUP 2012) 725, 730.

16 Pino, Diritti e interpretazione (n 1) 52-53; Alexy, A Theory of Constitutional Rights (n 14) 45ff and 86 ff. See also Barak, Proportionality (n 2) 86-89. Norms can sometimes assume the role of principles or of rules, according to Luigi Mengoni, Ermeneutica e dogmatica giuridica (Giuffrè 1996) 131-133.

17 Robert Alexy, 'Constitutional Rights, Balancing, and Rationality' [2003] Ratio Juris 131, 133-134; Alexy, 'The Construction' (n 15) 21.

18 Aharon Barak, 'Proportionality (2)' in Rosenfeld and Sajó (n 15) 738, 740; Robert Alexy, 'On Balancing and Subsumption. A Structural Comparison' [2003] Ratio Juris 433, 433-435. 
need to be weighed in order to ascertain which was the heavier, i.e. the more important. ${ }^{19}$ Indeed, 'rules are applicable in an all-or-nothing fashion', ${ }^{20}$ meaning that they can be either applied or not applied (there is no room for fudging); while principles need to be weighed, to be measured. While principles have the dimension of 'weight' or 'importance', which means that when they clash they have to be weighed one against the other, rules do not. ${ }^{21}$

This sharp distinction between the two categories has been contested by many scholars, who claim that although there may be differences, norms cannot be easily divided into one of the two categories. Distinctions are more blurred than they appear at first sight. ${ }^{22}$ Some scholars also hold that the same norm could be interpreted as a principle or as a rule, according to which specific argumentative mechanism (such as 'balancing') the court wanted to apply. ${ }^{23}$

The final aim of distinguishing between rules and principles is to create an axiological hierarchy among them, in which the former have to conform to, and not contrast with, the latter. ${ }^{24}$ Balancing is itself an argumentative technique that allows for the establishment of an axiological hierarchy between two norms, where one of the two is considered to prevail over the other, without necessarily invalidating it. ${ }^{25}$ Balancing allows the prevalence of one right over another to be decided in one particular case: it is not possible to state the prevalence of a given right in advance and/or 'once and for all'.26

19 Pino, Diritti e interpretazione (n 1) 52-53.

20 Dworkin (n 13) 24.

21 Ibid 26.

22 Pino, Diritti e interpretazione (n 1) 53-56, 72-76.

23 Ibid 72-76; Bin (n 15) 11-13; Guastini (n 10) 768. An Italian scholar proposes an additional classification that differentiates between constitutional principles and constitutional values: while principles are the normative formalization of cultural, ethical and moral values, values themselves would result in 'void concepts' if they were not incorporated into norms. Cf. Gino Scaccia, 'Il bilanciamento degli interessi come tecnica di controllo costituzionale' [1998] Giurisprudenza Costituzionale 3953, 3956.

24 In the words of Pino, Diritti e interpretazione (n 1) 73.

25 Ibid 178.

26 Bin (n 15) 33-42; Alexy, A Theory of Constitutional Rights (n 14) 96ff; Scaccia (n 23) 3964. There are nonetheless rights which are always given higher importance: Giorgio Pino, 'Conflitto e bilanciamento tra diritti fondamentali. Una mappa dei problemi' [2016] Etica \& Politica/Ethics \& Politics 1, 14; the same can be said with regard to freedom of speech in the American system. See 
Balancing consists in finding an equilibrated solution between the two sides of a set of scales, protecting both rights, trying not to sacrifice one in favour of the other; the solution adopted should be the one that allows one of the rights to be applied with the least sacrifice of the other. ${ }^{27} \mathrm{I}$ have been using the term 'rights' to indicate two conflicting claims brought before a court. In many cases, scholars and courts have used the term 'interests', ${ }^{28}$ understood as interests that obtain some normative acknowledgement. However, I believe that the term 'rights' is more straightforward and does not involve any substantive change. ${ }^{29}$ More particularly, the rights that enter into conflict and need to be balanced usually have the same hierarchical value; they may be, for instance, constitutionally entrenched rights. ${ }^{30}$ This is also true for the conflicting rights involved in the cases analysed here: as will be demonstrated in Chapters 2 and 3, both copyright and privacy are said to enjoy constitutional protection in each of the three systems examined, although in a different fashion. ${ }^{31}$

Clearly, not all constitutional rights have the same strength and importance: some can be considered 'superior' and should therefore prevail when they clash with other constitutional rights. ${ }^{32}$

I hope that, as we examine the cases below, the fact that a specific right can be considered prevalent in a given case, and not prevalent in another, even when the same rights are conflicting, will emerge clearly. This variance may depend on the different patterns of a given right.

below in this section on the difference between 'ad hoc' and 'definitional' balancing.

27 Pino, Diritti e interpretazione (n 1) 183. See also Robert Alexy's theory below Section 1.2.

28 'Interests' were considered by Roscoe Pound, 'A Theory of Social Interests' [1943] Harvard Law Review 1. See also Theodore M Benditt, 'Law and the Balancing of Interests' [1975] Social Theory and Practice 321. Consider also the distinction made by Scaccia (n 23) 3954-3957.

29 In this sense I share the view of Pino, Diritti e interpretazione (n 1) 185.

30 Ibid 186. Scaccia (n 23) 3957. This view clearly entails the prominence of the Constitution and of constitutionality rights over other rights and norms. This is something that I take for granted here, as a common principle of the current legal systems of the three countries analysed.

31 See specifically Chapter 2, Section 2 and Chapter 3, Section 2.

32 Gustavo Ghidini, Profili evolutivi del diritto industriale (Giuffrè 2015) 62. See also Barak, 'Proportionality (2)' (n 18) 752ff. The author recalls the classification of rights made in American constitutional law, which distinguishes between fundamental rights, equality and other rights. See also Section 3 of this chapter on the First Amendment of the American Constitution. 
Freedom of speech is a constitutional right in all three of the systems analysed; however, different kinds of speech exist and different 'freedoms of speech' are treated accordingly. This is the difference between 'abstract rights' and 'concrete rights', where every abstract right includes many different concrete rights, the latter being characterized by a higher specificity than the former. ${ }^{33}$ The difference between abstract and concrete rights is also reflected in (and mirrors) the distinction drawn by some scholars between two main categories of balancing: 'ad hoc balancing' and 'definitional balancing' ${ }^{34}$ The former refers to cases where balancing is achieved on a 'case-by-case' basis, while the latter implies a more general and universal balancing. Ad hoc balancing results in a decision which is only valid and true for the specific case at issue. The same 'balancing rule' cannot be applied to other subsequent cases; in fact, given that each case presents its own peculiarities, there are no identical cases in which the same rule can be applied. This does not mean that there are no rules governing ad hoc balancing; rather that the exceptions and idiosyncrasies characterizing each case will lead the interpreter to different solutions for different cases. The axiological hierarchy is therefore 'movable', 35 i.e. it is applicable only to the specific case under scrutiny. Ad hoc balancing has been harshly criticized because it allegedly 'undermine[s] the development of stable, knowable principles of law'. ${ }^{36}$ It also supposedly allows judges to be influenced by 'strong popular feelings'. ${ }^{37}$

We have a different scenario when courts apply 'definitional balancing'. Here courts identify a specific rule that could also be applicable to

33 Pino, Diritti e interpretazione (n 1) 184.

34 While 'ad hoc balancing' had been recognized by previous scholars, the distinction between it and 'definitional balancing' was first made by Nimmer (n 6) 938-945. See also Aleinikoff (n 6) 597-598, who calls 'ad hoc balancing' and 'definitional balancing' respectively 'result-balancing' and 'rule-balancing'. Consider also the difference between a 'basic balancing rule' - akin to an ad hoc balancing - and a 'specific balancing rule': Barak, Proportionality (n 2) 367-369.

35 Pino, Diritti e interpretazione (n 1) 189. This definition was first introduced by Guastini (n 10) 776. According to Guastini this means leaving discretion to courts.

36 Aleinikoff (n 6) 948.

37 Nimmer (n 6) 940 and 944. On the influence of society and culture on judges, when balancing conflicting rights, see Federica Giovanella, 'Effects of Culture on Judicial Decisions. Personal Data Protection vs. Copyright Enforcement' in Roberto Caso and Federica Giovanella (eds), Balancing Copyright Law in the Digital Age. Comparative Perspectives (Springer Verlag 2015) 65. 
future cases. $^{38}$ This rule would be applicable whenever balancing involved the same rights. Hence, while definitional balancing rules are normally both explicit and stable, ad hoc balancing rules are implicit and prone to error.

To determine whether balancing has been made 'ad hoc' or with a 'definitional meaning', one should look at the way that courts - other than the one that made the balance - go on to apply the rule. When other judges tend to apply it in subsequent cases with neither modification nor objections, that balancing rule is definitional; when the contrary occurs, the balancing was ad hoc. ${ }^{39}$

The concept of 'principled balancing' is very similar to that of 'definitional balancing'; it was introduced by Aharon Barak, according to whom the rules of balancing 'would be formulated at a level of abstraction below that of the basic rule but above that of concrete balancing'. ${ }^{40}$ Barak's principled balancing would differ from 'definitional balancing', for the former 'is based on a balance struck within the framework of a right of a given scope'. ${ }^{41}$

Balancing can more easily be defended from criticism when it is based on tests or other 'specific guides'. ${ }^{42}$ Although, as mentioned, 'case-bycase' balancing has been criticized by many, it is also said to be a better way to solve conflicts than is definitional balancing. In fact, even though an ad hoc approach obviously decreases the foreseeability of any single decision, the judgment will nonetheless correspond better to the need for justice in that particular case. ${ }^{43}$

The distinction between ad hoc and definitional balancing may, in fact, merely be apparent: it may always be possible to find differences and peculiarities in each case, rendering former rules inapplicable and new ones desirable, and thus leading perforce to 'ad hoc balancing'. ${ }^{44}$ In fact, whenever a court balances rights, it should consider the peculiarities of the case before it. As a consequence, definitional balancing, which can in

38 Nimmer (n 6) 944; McFadden (n 1) 600-601.

39 Pino, Diritti e interpretazione (n 1) 202.

40 Barak, 'Proportionality (2)' (n 18) 747; Aharon Barak, 'Proportionality and Principled Balancing' [2010] Law \& Ethics of Human Rights 1, $12 \mathrm{ff}$.

41 Barak, 'Proportionality and Principled Balancing' (n 40) 14.

42 Luizzi (n 11) 394.

43 Scaccia (n 23) 3995. Consider also the words of Stone Sweet (n 6) 11: '[b]alancing standards hold sway precisely where the law is (a) most indeterminate and (b) most in danger of being constructed in a partisan way'.

44 Pino, Diritti e interpretazione (n 1) 191; Aleinikoff (n 6) 979-980; McFadden (n 1) 635; Bin (n 15) 149. 
theory improve the certainty of decisions, would in fact reduce their coherence. ${ }^{45}$ Some authors hold that balancing can never be a 'once and for all' solution: each balancing is connected to the circumstances of the case, and the hierarchical classification arising from that balancing is concrete and flexible. ${ }^{46}$

Regardless of whether there really are two distinct 'balancing methods', or they are just two sides of the same coin, or even two poles between which a wide variety of other methods are ranged, ${ }^{47}$ it remains the case that when a rule is adopted by a superior court, this rule constitutes a precedent that will be - to a greater or lesser extent, depending on numerous factors ${ }^{48}$ - applied in subsequent cases not just by the court that set the rule, but also by lower courts. Clearly, when a court does not explicate the standard it has applied, i.e. when - in Aleinikoff's words - 'the balancing takes place inside a black box' ${ }^{49}$ the reliability of its balancing is more open to question and the replicability of the decision as a rule decreases dramatically. The same would be true for predictability, with the consequence that like cases would not be treated alike. ${ }^{50}$

Another possible distinction has been made between constitutional balancing and interpretative balancing. The first is meant to determine the constitutionality of a law, while the second is used to determine the aims and scope of the interpreted law. ${ }^{51}$

Conflicts in which courts have to weigh clashing rights are also divided into 'concrete conflicts' and 'abstract conflicts'. The latter can be solved through textual interpretation as the conflict remains at a conceptual level and does not have to be grounded in an actual case. The former

45 Aleinikoff (n 6) 979.

46 Scaccia (n 23) 3965 and 3967. The author maintains that 'definitional' or 'categorical balancing' would not be balancing in the proper sense, but rather an interpretation technique. The author also holds that the Italian Constitutional Court approach differs from that of the US Supreme Court, as the former's decisions have general and future validity, while the latter's would not. Ibid, 3967-3968.

47 Pino, Diritti e interpretazione (n 1) 193.

48 This is clearly different in common law vs. civil law systems, but it also depends on other factors such as, for instance, the need for equal treatment of equal situations or the need for coherence within the entire legal system. Ibid 192.

Aleinikoff (n 6) 976.

50 McFadden (n 1) 645-650. The author maintains that balancing 'requires a tolerance for general or system unpredictability' (at 650, emphasis in original).

51 Barak, Proportionality (n 2) 347. 
are cases where in applying norms to an actual case, the interpreter realizes that two norms lead to two different, and incompatible, consequences. Hence, while abstract conflicts descend from the same structure of normative language, concrete ones depend on what happens in real life. 52

Balancing has not only been criticized in its 'internal' composition and functioning, ${ }^{53}$ but also in its 'external' implications. Aleinikoff offers a thorough critique of all facets of balancing. ${ }^{54}$ There are, of course, also opposing voices, according to whom balancing is a technique that encourages courts to better motivate their judgments, thus increasing the transparency of decisions..$^{55}$

More generally, the legitimacy of the balancing done by courts, as opposed to that of legislators, has been questioned. Proportionality is considered the domain of legislators, while preserving the boundaries of proportionality is the domain of the courts. ${ }^{56}$ Whereas the legislature might be the better forum within which to balance interests, due to its participatory nature, ${ }^{57}$ the courts could theoretically improve the balancing already done by the legislator, as they are more aware of the social context and of the impact of the interpretation of the Constitution. However, it has been argued that balancing is not the best instrument for 'the check and validating functions of constitutional law'58 and that courts can also take social context into account while adopting approaches other than that of balancing. ${ }^{59}$ Some maintain that judicial balancing could ultimately undermine the democratic standard as it demonstrates distrust in the functioning of Parliament. ${ }^{60}$ This concern, however, should be viewed in the light of the relationship between courts and the legislative branch: whenever the former take into account the

52 Guastini (n 10) 773-774.

53 Aleinikoff (n 6) 972-983.

54 Ibid, in particular $984 \mathrm{ff}$.

55 Vicki C Jackson, 'Constitutional Law in an Age of Proportionality' [2015] Yale Law Journal 3094, 3143.

56 Barak, 'Proportionality (2)' (n 18) 748.

57 McFadden (n 1) 641-642.

58 Aleinikoff (n 6) 984-995.

59 Ibid (n 6) 1001-1002; Nimmer (n 6) 940.

60 Schlink (n 15) 735-736. Contra: Barak, 'Proportionality (2)' (n 18) 749-751; Robert Alexy, 'Balancing, Constitutional Review, and Representation' [2005] International Journal of Constitutional Law 572, 578-581. 
latter's will and aims, and respect them, ${ }^{61}$ the above objection becomes meaningless.

Aleinikoff's critique also included the idea that balancing had become 'mechanical jurisprudence', no longer able to persuade, ${ }^{62}$ and rigid and formulaic. ${ }^{63}$ This assessment is probably more appropriate to what has been called 'definitional balancing', than to 'case-by-case' balancing.

Many other critiques have been presented, some of which concern the opportunity for judges to be discretional. ${ }^{64}$ While some authors dislike judges' discretion, ${ }^{65}$ others consider it normal that they should make law (as when applying the method of balancing), although in a different manner to that used by legislators. ${ }^{66}$

\subsection{Theories of, and Approaches to, 'Rights Balancing'}

The practice of balancing is described by scholars either as a rational activity or as a solely intuitive process. The latter approach holds balancing to be a highly subjective activity, heavily coloured by the personal beliefs and opinions of the individual judge approaching the case $^{67}$ and inevitably an ideologically driven operation.

Although it is undeniable that judges bring their personal feelings and perceptions to each decision they make, ${ }^{68}$ it is also the case that to consider all that judges do to be ideologically driven and subjective would undermine the basis of the modern judiciary, and be tantamount to

61 Aharon Barak is critical of the way some courts 'submit' themselves to the legislative branch: Barak, 'Proportionality (2)' (n 18) 748.

62 Aleinikoff (n 6) 983.

63 Ibid 1005.

64 See contra: Mengoni (n 16) 125. See also the explanations offered by Alexy, A Theory of Constitutional Rights (n 14) 394ff.

65 Dworkin (n 13) 81ff. On judicial discretion: see Ibid, 69-71.

66 Stone Sweet and Mathews (n 11) 87. Consider also Richard A Posner, Reflections on Judging (Harvard University Press 2013), especially 108-126.

67 McFadden (n 1) 643ff. The author believes that this leaves space for inconsistency. According to Jacco Bomhoff, 'Rights, Balancing \& Proportionality' [2010] Law \& Ethics of Human Rights 109, 132-138, balancing discourse in Germany and in the US has been subject to different kinds of criticisms.

68 'Balancing is unavoidably subjective and political' according to Schlink (n 15) 726. '[S]ubjective appraisals of the judges ... will necessarily appear in balancing or in any alternative procedure': Carlos Bernal Pulido, 'The Rationality of Balancing' [2006] Archives for Philosophy of Law and Social Philosophy 195, 197-198. 
saying that no objective criteria for assessing the admissibility of judicial decisions exist. 69

An opposite approach is taken by the scholars who describe balancing as a rational process. Barak, for instance, holds that balancing could be rational since it is based on 'the social importance of realizing one principle and avoiding limitation of another principle'. Allowing judges some discretion does not entail a lack of rationality. ${ }^{70}$

The most prominent of the scholars supporting a rational view of 'balancing' is Robert Alexy, who proposes an extremely analytic and procedural method of balancing in his influential work, A Theory of Constitutional Rights. ${ }^{71}$

As a German scholar, Alexy mainly draws his theory - based on the assumption that principles differ from rules $^{72}$ - from the Bundesverfassungsgericht's decisions, which are based on the application of the 'principle of proportionality' to cases of conflicting constitutional principles. ${ }^{73}$

Proportionality itself is typically divided into three phases or subprinciples: suitability, necessity, and proportionality in its narrow sense. ${ }^{74}$ This is the approach adopted in Robert Alexy's seminal works. ${ }^{75}$

Whether or not a measure limitative of a fundamental right is suitable for realizing the aims for which it was enacted determines its suitability.

69 Pino, Diritti e interpretazione (n 1) 194. See also Dworkin (n 13) $81 \mathrm{ff}$. Contra: Bernal Pulido (n 68) 205ff; Jackson (n 55) 3159 holds that 'there is good reason to think that, in some discrete areas, U.S. constitutional law could benefit from greater use of both the principle and the structured doctrine of proportionality' (emphasis added). See ibid 3166ff.

70 Barak, 'Proportionality (2)' (n 18) 750.

71 Alexy, A Theory of Constitutional Rights (n 14); see also Alexy's other papers cited in this chapter.

72 In this respect, Alexy's view originates from Dworkin's, although it does differ from it: Vespaziani (n 11) 93 and 95ff; Kai Möller, 'Balancing and the Structure of Constitutional Rights' [2007] International Journal of Constitutional Law 453, 454-455.

73 This is the so-called 'Verhältnismäßigkeitgrundsatz': Alexy, 'Constitutional Rights' (n 17) 135ff.

74 'Proportionality in the narrow sense' is also known as 'balancing in the strict sense' according to Stone Sweet and Mathews (n 11) 75.

75 Alexy, 'Balancing' (n 60) 572; A Theory of Constitutional Rights (n 14) 66ff. 
If the limitative measure cannot achieve the aims for which it was implemented, it can be considered illegitimate at this very first stage. ${ }^{76}$

Once its suitability has been ascertained, a measure's necessity must be evaluated. This means understanding whether the measure adopted is less invasive of citizens' rights than any of the possible alternatives - all of which are appropriate to achieve the aim of the legislator. When a given measure is suitable to achieve the (legitimate) intended aim and is also a necessary measure, the third step, proportionality in its narrow sense, must be assessed. This final step is in fact the actual activity of balancing: its goal is to determine whether the sacrifice imposed on the fundamental right by the adopted measure is balanced, taking into account the degree of satisfaction of the public interest realized by the measure itself. ${ }^{77}$

Alexy's whole theory is based on the concept of 'Pareto-optimality'. In economics, a Pareto-optimal point of equilibrium is one where the position of a part can be improved without detriment to any other. In Alexy's analysis, Pareto-optimality applies both to suitability and to necessity. With regard to sustainability, a Pareto-optimal approach would consider a means that obstructs the realization of one principle without promoting another to be non-suitable. ${ }^{78}$ When two means are equally suited to promoting the same interest, the necessity principle requires that the one that interferes less with the opposite principle should be preferred. ${ }^{79}$

The most innovative idea in Alexy's theory is probably the so-called 'Law of Balancing', which states: 'The greater the degree of nonsatisfaction of, or detriment to, one principle, the greater the importance of satisfying the other.' ${ }^{80}$ This law can also be divided into three steps: first, one should understand the degree to which the first principle is not satisfied; second, the importance of satisfying the opposite principle

76 Pino, Diritti e interpretazione (n 1) 206. This step implies also checking whether the aim at which the measure is directed is legitimate in itself.

77 Ibid 207.

78 Alexy, 'Constitutional Rights' (n 17) 135. Criticism of the idea of optimization of rights can be found in Möller (n 72) 459-462.

79 Alexy, 'Constitutional Rights' (n 17) 135: such an approach requires that no third principle enters into play. For a critique, see Pino, Diritti e interpretazione (n 1) 196-199.

80 Alexy, A Theory of Constitutional Rights (n 14) 102ff. In similar terms: Barak, 'Proportionality and Principled Balancing' (n 40) 11. 
should be established; lastly, it should be decided whether the importance of satisfying the second principle justifies the detriment to the first one. ${ }^{81}$

The interference with the first principle is proportionate when, in the absence of such interference, another constitutionally protected right would undergo equivalent, or major, interference. ${ }^{82}$

Intensity of interference and degrees of importance are evaluated following a 'triadic scale' on which the three illustrated steps are considered 'light', 'moderate' or 'serious'; the scale can also be developed to a 'double-triadic' model, allowing more nuances to be taken into account. ${ }^{83}$ The establishment of such a triadic scale should overcome the difficulties linked to incommensurability. ${ }^{84}$

In Alexy's view, intensity of interference is the first value to be considered, since the conflicting rights are of equal weight in the abstract. If this were not the case - if the two rights did not have the same weight in the abstract - no balancing would be needed. The importance of satisfying the second principle is a function of the interference with the first principle: the possible effects that omitting to interfere with the first principle might have on the second must be considered. ${ }^{85}$ The triadic scale would allow a weight to be assigned to the principles in the concrete case. Weight, represented as numbers, is then processed using a mathematical formula, which should enable precise balancing. ${ }^{86}$ To improve balancing, Alexy suggests an additional 'second Law of Balancing': 'The more heavily an interference with a constitutional right weighs, the greater must be the certainty of its underlying premises.' 87 The picture becomes more complicated when a third (or more) right(s) enter(s) into it. ${ }^{88}$

Alexy's approach undoubtedly has a number of advantages, such as the precision of the balancing process involved, and the ease with which the operations entailed in one particular case can be replicated in subsequent cases. However, it is probably not as feasible as Alexy imagined it to be.

\footnotetext{
81 Alexy, 'Constitutional Rights' (n 17) 136.

82 Ibid 38.

83 Alexy, 'On Balancing and Subsumption' (n 18) 440-445 passim.

84 Ibid 442.

85 Ibid 440-441.

86 Ibid 442-446. Even though he did not refer to Alexy's theory, Scaccia (n 23) 3958 holds that balancing can never be boiled down to a logicalmathematical operation.

87 Alexy, 'On Balancing and Subsumption' (n 18) 446; Id, A Theory of Constitutional Rights (n 14) 418-419. The author himself renames the two Laws, calling them 'Substantive Law of Balancing' and 'Epistemic Law of Balancing'.

88 Alexy, 'On Balancing and Subsumption' (n 18) 448.
} 
Determining the weight of each right and the degree of interference the conflicting rights experience is no easy task. ${ }^{89}$ Moreover, the attribution of a given weight to a specific right seems to be made 'in a vacuum', while, as other scholars have observed, the weight of each right can only be determined in relation to the opposite, conflicting right. ${ }^{90}$

A number of criticisms have been made of both the idea of the three-step proportionality test and the way in which Alexy's formula further rationalizes this procedure. ${ }^{91}$ Improvements to the formula have also been suggested. 92

Some scholars do not even accept the basic division of proportionality into three steps. ${ }^{93}$ All the proposed approaches have proportionality stricto sensu as their final stage; however, while some authors maintain that this last step is in itself the balancing process, ${ }^{94}$ others consider it to be only a part of that process. ${ }^{95}$ Others hold that the first of the three steps already entails a balancing activity, or that the procedure is over-simplified, as a single measure may often be pursuing different goals simultaneously. ${ }^{96}$ If this were the case, Alexy's approach should not

89 Ricardo A Guibourg, 'On Alexy's Weighing Formula' in Jan-Reinard Sieckmann (ed), Legal Reasoning: the Methods of Balancing (Franz Steiner Verlag 2010) 145, 154-157.

90 Pino, Diritti e interpretazione (n 1) 197.

91 Scaccia (n 23) 3977-3978, who is critical of any type of economic approach to balancing; Pino, Diritti e interpretazione (n 1) 196-199 and Pino, 'Conflitto e bilanciamento' (n 26) 34-36; Bernardo Bolaños, 'Balancing and Legal Decision Theory' in Sieckmann (ed) (n 89) 63, 71-72; Jan-Reimand Sieckmann, 'Balancing, Optimisation, and Alexy's "Weight Formula", in Sieckmann (n 89) 101. For an overview of the many different objections raised to Alexy's theory and, more generally, to the balancing of principles: Alexy, 'The Construction' (n 15) 24-26; Luizzi (n 11) 386-400. For an overview of other objections and an answer to them, as well as for some possible solutions to reduce the risks linked to balancing, ibid 401-403.

92 Bernal Pulido (n 68) 205-209.

93 Schlink (n 15) 722-725, who considers categorically prohibited means, legitimacy of the end, fitness or suitability, and balancing. Barak, 'Proportionality (2)' (n 18) 742-747, who recognizes 'proper purpose, rational connection, necessity, and proportionality in the narrow sense'.

94 Barak, 'Proportionality and Principled Balancing' (n 40) 7.

95 Balancing is seen by scholars both as a framework for proportionality analysis and as the last step of the proportionality test. See Schlink (15) 719, and cited references.

96 Pino, Diritti e interpretazione (n 1) 208-209. 
be a model of reasoning for courts, but rather a mechanism for understanding what factors should be evaluated in order to reach a proportionate solution. ${ }^{97}$

A different approach is adopted by Aharon Barak, who takes into account not only the degree of limitation of the right, as Alexy does, but also the importance of the purpose and the magnitude of the constitutional right itself. Specifically, Barak's vision includes the social importance of rights: the social importance of the benefit obtained by realizing the purpose of a particular law, and the social importance of avoiding the limitation of the constitutional right in question..$^{98}$

Another possible approach is described by some Italian authors, who, with reference to the balancing applied by the Italian Constitutional Court, propose the following three-step interpretation process: the interpreter should first identify the values compromised by the statute the constitutionality of which is under scrutiny; second, the weight of those rights in the specific case should be evaluated; third, it should be understood what public interest does the statute intend to serve by sacrificing the constitutionally protected values in play. ${ }^{99}$

The Italian scholar Roberto Bin, who studied numerous Constitutional Court decisions, identified some specific steps that the Court takes in making its judgments, the first of which is to draw what Bin calls the 'topography of the conflict': investigating whether the area protected by one right does in fact overlap with the area protected by the other one, and what residual area - other than the overlapping one - is left to both rights. ${ }^{100}$ Bin considered such an approach to be akin to the US Supreme Court's definitional balancing. ${ }^{101}$

This preliminary activity should make it possible to define if and how a right actually undergoes a restriction, and also whether such a restriction is absolutely impairing for that right, or only limits it partially. The first step of the Court would therefore be to understand whether the interest protected by the constitutionally challenged law could justify the compression of the constitutional right. ${ }^{102}$

Proportionality itself is being applied not only by the Bundesverfassungsgericht, but also by an increasing number of other Supreme Courts,

\footnotetext{
97 Ibid 209.

98 Barak, 'Proportionality (2)' (n 18) 745-746.

99 Scaccia (n 23) 3972-3973; see also Bin (n 15) $62 \mathrm{ff}$.

100 Ibid 62-63.

101 Ibid 65-68. Critiques of Bin's work can be found in Vespaziani (n 11)

102 Bin (n 15) 70-72.
}

127. 
including the Court of Justice of the European Union (CJEU). The proportionality principle was invoked by the CJEU in the seminal case Promusicae, for example, as will be illustrated when discussing the case studies. ${ }^{103}$ Proportionality is rarely explicitly mentioned by Constitutions or charters, but its existence is said to be grounded in the ontological construction of human rights and public interest. ${ }^{104}$

Proportionality and balancing are closely intertwined: they both look at the limitation of a specific right or principle. In addition, proportionality can be seen as one step within a wider balancing process. ${ }^{105}$

The Italian Constitutional Court does not apply the proportionality principle; however, it has elaborated a 'reasonableness criterion', which can be equated to proportionality. ${ }^{106}$ The Court has elaborated certain criteria for balancing the conflicting interests in cases where a statute is challenged because of its unconstitutionality. These criteria include the ideas of 'tempering opposite interests', 'least invasive means' and 'coessential limits'. ${ }^{107}$ When the first criterion is applied, neither of the two conflicting rights is totally sacrificed. The 'least invasive means' criterion requires that fundamental rights are invaded as little as possible in the realizing of another constitutionally relevant interest. ${ }^{108}$ The third criterion provides that a fundamental right cannot be compressed unless this is done to protect other fundamental constitutional values, and applying only non-excessive and strictly necessary means. ${ }^{109}$

Although it has theorized and applied these rules, the Italian Constitutional Court has never classified rights. In fact, even though courts 'are loath to build intra-constitutional hierarchies of norms' 110 and decide on a case-by-case analysis, some do nonetheless consistently apply specific tests or criteria. However, the Italian Court has never proposed consistent

103 Case 275/06 Productores de Música de España v. Telefónica de España SAU [2008] ECR I-00271, on which see Chapter 4, Section 5.1.

104 Barak, 'Proportionality (2)' (n 18) 741-742.

105 Pino, Diritti e interpretazione (n 1) 205.

106 Scaccia (n 23) 3975.

107 Translation is mine from the Italian: 'contemperamento', 'minimo mezzo', 'coessenzialità del limite': Scaccia (n 23) 3973-3985.

108 Bin (n 15) 81ff.

109 Scaccia (n 23) 3992.

110 Stone Sweet and Mathews (n 11) 87 (emphasis in original). 
balancing tests or criteria, ${ }^{111}$ unlike the Supreme Courts of both the US and Canada, which have developed tests to be applied in specific cases. ${ }^{112}$

The Canadian Supreme Court famously applies the so-called 'Oakes test', which originated in $R$. v. Oakes. ${ }^{113}$ The test, which has been developed in subsequent decisions, involves Section 1 of the Canadian Charter of Human Rights and Freedoms. ${ }^{114}$ This section states that the Charter 'guarantees the rights and freedoms set out in it subject only to such reasonable limits prescribed by law as can be demonstrably justified in a free and democratic society'. While the burden of proving the infringement of a right is borne by the challenger, the Court has to investigate the scope of the allegedly violated right. The judges need to understand whether the government acted legally and for reasons that are 'pressing and substantial in a free and democratic society'. If this is not the case, the procedure ends. If, however, the government proves that its action is justifiable, the Court proceeds with a three-step test: it assesses first whether the means chosen are rationally related to the legitimate object; second, whether they impair the protected rights to the minimum extent possible; third, whether the government's aims justify the harm to the right protected by the Charter. This final step is known as 'proportionality as such'. 115

111 Scaccia (n 23) 3963.

112 See, for instance, the test developed by Justice Harlan in Katz v. United States, 389 U.S. 347 (1967), 361, on which see Chapter 3, Section 2.

113 R. v. Oakes [1986] 1 S.C.R. 103, for a critique of which see: Sujit Choudhry, 'So What Is the Real Legacy of Oakes? Two Decades of Proportionality Analysis under the Canadian Charter's Section 1' [2006] South Carolina Law Review 501. For a comparison between the approaches taken by the US and Canada, see Jackson (n 55); for a comparison between the Canadian and the German approaches, see Dieter Grimm, 'Proportionality in Canadian and German Constitutional Jurisprudence' [2007] University of Toronto Law Journal 383. See also Stone Sweet and Mathews (n 11) 113ff.

114 Canadian Charter of Rights and Freedoms, Part I of the Constitution Act, 1982, being Schedule B to the Canada Act, 1982, c. 11 (U.K.). The Charter is a Bill of Rights included in the Constitution Act of 1982, through which Canada obtained full political autonomy from the United Kingdom. The rights contained in the Charter are considered constitutional rights; hence they can override any state or federal law that clashes with them.

115 For more details: Jackson (n 55) 3111-3113. The author reports that generally the Canadian Supreme Court finds laws unconstitutional under the 'minimally impairing' requirement (Ibid 3117). The entire procedure is actually based on a four-step test: Choudhry (n 113) 505. 
While the approach adopted by the Canadian Supreme Court is quite similar to the German one, that followed by American judges seems to be different. Many scholars have examined the method applied in the American system where, to quote the title of Aleinikoff's article, 'constitutional law [has been] in the age of balancing' for many years. ${ }^{116}$ The US Supreme Court applies balancing tests to many different areas of the law, including the Eighth Amendment, related to excessive bail, excessive fines, or cruel and unusual punishment; ${ }^{117}$ the Fourth Amendment on the right of people to be secure against search and seizure; 118 and, of course, the First Amendment on freedom of speech. ${ }^{119}$

Even though balancing is ubiquitous in American case law, applicable tests, standards or rules vary according to the rights at stake. ${ }^{120}$ For instance, as in First Amendment cases, the Court has often applied a test including 'the seriousness of the speech-related harm the provision will likely cause, the nature and importance of the provision's countervailing objectives, the extent to which the provision will tend to achieve those objectives, and whether there are other, less restrictive ways of doing so'. ${ }^{121}$ The Court essentially assesses 'the need for a sufficiently important or "compelling" government purpose; the rational connection required between the means chosen and the end; and the "minimal impairment" inquiry into whether there are less restrictive means towards the same goal'.122 These steps do constitute, in essence, a test of proportionality. ${ }^{123}$

It must be stressed that differences in approach can also be the result of differences in the function, tools and aims of the courts. While the US Supreme Court can dictate what the solution should be in a concrete case, the Italian Corte costituzionale gives general prescriptions; from this point of view, its decisions can very often be assimilated to 'definitional balancing' ones. ${ }^{124}$

\footnotetext{
116 Aleinikoff (n 6).

117 Jackson (n 55) 3104.

118 See for instance the famous case Katzs (n 112) or more recently Kyllo v. United States, 533 U.S. 27 (2001) and U.S. v. Jones, 132 S. Ct. 945 (2012).

119 On which consider the seminal article by Nimmer (n 6).

120 "From this identification of balancing techniques, it becomes clear that the number of models is many and that the term, "balancing of interests," refers to no single method of judicial decision making': Luizzi (n 11) 386.

121 United States v. Alvarez, 132 S. Ct. 2537 (2012), 2551.

122 Jackson (n 55) 3099.

123 Alvarez (n 121), 2551.

124 Bin (n 15) 125-126.
} 
Vincent Luizzi has categorized US Supreme Court decisions into two main groups: the first includes 'models where judges follow specific guides' and 'models where rules guide the balance';125 the second comprises decisions that do not explicitly follow any specific rule or guide. The first group of the first category comprises those decisions in which one of the interests at stake has been nominated as 'compelling' or 'substantial' and therefore has prevailed over the other. The second group of the first category comprises judgments that have followed an explicit rule, test or standard. Tests themselves constitute a part of the balancing process. ${ }^{126}$ This is consistent with the approach adopted by the courts in resolving the conflict between information privacy and copyright in the lawsuits taken here as case studies. Cases resolved on the basis of a test may also be classified as 'definitional balancing' according to the reported definition.

The decisions grouped in the second category, in contrast, do not take a substantial or compelling right as the starting point for their balancing; instead they identify the 'paramount' interest solely on the basis of their balancing of the particulars of each case. ${ }^{127}$ In Luizzi's view, this is genuine balancing, while when courts first search for the prevailing interest, no true balancing can actually take place. ${ }^{128}$ In his seminal article on 'the age of balancing', Aleinikoff takes a different view. In his opinion, both cases where the US Supreme Court decides that one interest outweighs the other, and those in which the Court more properly strikes a balance, can be considered as 'balancing'. ${ }^{129}$

The absence of consensus on the exact nature of balancing, and how it should be accomplished, mirrors the evolution of the state of the law: a transition from procedural rules and deductions to the balancing of principles and values. The latter approach is the expression of the contemporary constitutional legal order. ${ }^{130}$

In the next section I will first illustrate the kind of conflict the courts resolved in the case studies considered here and then propose a hypothesis for what I call 'conceptual balancing'. Both the conflict under discussion and how the courts in each of the three countries resolved (or have attempted to resolve) it will be examined. It will emerge that in Canada and the US courts apply a specific test when deciding whether

\footnotetext{
125 Luizzi (n 11) 377-386.

126 Ibid 378-383.

127 Ibid 383-385.

128 Ibid 388-389.

129 Aleinikoff (n 6) 946.

130 Vespaziani (n 11) 129.
} 
information privacy should be overridden to allow copyright enforcement, while a different approach is adopted by Italian judges. This is consistent with the approaches of the three countries' Supreme Courts, as we have seen above.

\section{THE CONFLICT}

Neither this chapter - nor this book as a whole - aims to define balancing or how it should be carried out; the intention is to compare the ways in which the lower courts of the three countries in question actually apply this methodology. This comparison is made through case studies involving two rights which are usually considered to be fundamental: copyright and (information) privacy, as illustrated in detail in the present section.

The cases examined in this book are examples of one of the most recent steps taken by the music industry, and the entertainment industry more generally, to stop what is usually known as 'copyright piracy'. Broadly speaking, copyright piracy consists in the reproduction and diffusion of copyrighted material without the consent of the copyright holder.

Copyright piracy has now existed for decades, but has only become a worldwide phenomenon with the spread of the Internet. Tape cassettes, and then CDs, were commonly copied among friends. Pirate copies of both types of medium were quite easily accessible on the "parallel market' but their existence and circulation were largely tolerated by copyright holders.

With the advent of the Internet and then of MP3 files, sharing songs around the globe became easy, cheap and fast; significantly, this file compression format resulted in much smaller files than previous data formats. ${ }^{131}$ This led the recording industry to adopt a number of different strategies in an attempt to combat online piracy.

131 MP3 - full name MPEG audio level 3 - is 'a way of encoding digital audio data into a compressed data format that is approximately one twelfth the size of the original without perceptible loss of quality ... Because MP3 files are compact and easy to copy, they are relatively quick to download and very easy to distribute - which is causing problems for the original artists who are trying to protect their copyright material', Entry: MP3 in Simon MH Collin, Dictionary of Computing (Peter Collin Publishing 2004). 
Going back to the years in which analogue copying was a novelty, a quick reference to the seminal case Sony v. Universal ${ }^{132}$ should be made. Although I will analyse this decision in greater detail in Chapter 4, a particular aspect of the case is relevant here, an aspect, indeed, which is usually overlooked - the fact that in Sony v. Universal privacy concerns were also raised.

As is well known, Sony was sued for contributory infringement of copyright laws for manufacturing and selling the Betamax, a videorecorder which could be used by individuals to record television programmes on video tapes in order to watch them at a more convenient time; the practice was known as 'time-shifting'. The plaintiffs were Universal City Studios and Walt Disney, the producers and copyright owners of many of the television programmes and popular shows airing when Betamax was released. In their opinion, since consumers used Betamax to record copyrighted works, the defendants were liable for copyright infringement under the US Copyright Act. The lawsuit was focused on vicarious liability and contributory infringement, to which I shall return in Chapter 4.

Even though the most famous decision in this case is that of the US Supreme Court, the District Court for the Central District of California made a remark of relevance to the core of my present analysis. Ferguson $\mathrm{J}$ recognized that taking copyright enforcement to the level requested by the plaintiffs would mean entering private homes. Private behaviour, such as home-recording, would be very difficult to control. In the legislative process leading up to the 1976 revisions to the Copyright Act, in fact, the Copyright Office was concerned 'about invasion of the individual's privacy in his home'. At the same time, the District Court understood that

Of course, not all activity is made legal by virtue of occurring in a private home. Congress can constitutionally legislate against some activity which may occur in the home, but doing so necessarily requires caution. Here, legislative history shows that, on balance, Congress did not find that protection of copyright holders' rights over reproduction of their works was worth the privacy and enforcement problems which restraint of home-use recording would create. ${ }^{133}$

132 Universal City Studios, Inc. v. Sony Corp. of America, 480 F. Supp. 429 (C.D. Cal. 1979); Universal City Studios, Inc. v. Sony Corp. of America, 659 F.2d 963 (9th Cir. 1981), Sony Corp. of America v. Universal City Studios, 464 U.S. 417 (1984). Dozens of comments have been written on this case, see Chapter 4 for bibliography.

133 Sony Betamax District court (n 132) 445-446 passim. On this issue see Sonia K Katyal, 'Privacy v. Piracy' [2004] Yale J. Law \& Tech. 222, 309ff. 
According to Judge Ferguson, in this case it was Congress which had struck the balance between consumer privacy and copyright enforcement.

The case highlights how, in order to enforce copyright, intrusion into the privacy sphere of the alleged infringers is necessary. This is closely analogous both to the cases analysed in this book and to the conflict on which my research focuses. More recently, this onerous task appears to have been shifted to the courts, which are finding it difficult to cope with, as will be demonstrated throughout this work.

Sony Betamax - a case in which, in order to limit copyright infringement, copyright holders sued a subject (Sony) for being 'indirectly liable' - is undoubtedly one of the most famous cases of copyright enforcement in the 'analogue era'. However, this has been only one of a number of strategies adopted by the entertainment industry in their efforts to stop the infringing activities of final users. ${ }^{134}$

Twenty years after the Sony case, the Recording Industry Association of America (RIAA), ${ }^{135}$ which represents the interests of the US recording industry and the holders of music copyright, started a number of lawsuits aimed at enforcing copyright against users allegedly liable for online piracy. The same strategy was followed in subsequent years by other copyright holders' associations, both within and outside the US. ${ }^{136}$

The starting point of these lawsuits, regardless of whether they took place in Europe, Canada or the US, was the same. Copyright holders had reason to believe that their works were being illicitly distributed through peer-to-peer file-sharing networks.

In order to pursue their strategy - i.e. the enforcement of copyright against final users - copyright holders need to discover the real identities hidden behind computers; users are usually only identifiable through their pseudonymous or Internet Protocol (IP) addresses. ${ }^{137}$ Copyright holders rely on service companies, who collect data on peer-to-peer

134 See Chapter 4, Section 1 for further details.

135 'The Recording Industry Association of America (RIAA) is the trade organization that supports and promotes the creative and financial vitality of the major music companies. Its members are the music labels that comprise the most vibrant record industry in the world. RIAA members create, manufacture and/or distribute approximately $85 \%$ of all legitimate recorded music produced and sold in the United States', see RIAA's website <www.riaa.com/aboutus.php $>$ accessed 10 February 2017. According to Robert P Merges, Peter S Menell and Mark A Lemley, Intellectual Property in the New Technological Age (5th edn, Aspen 2010) 682, the RIAA represents more than 500 companies related to the creation, manufacturing and distribution of sound recording.

136 For a detailed description of these cases, see Chapter 4.

137 For a definition, see below in this section. 
traffic. Using a variety of methods, these service companies can crawl the network and find and collect the IP addresses of users, which they give to the copyright holders who then require the collaboration of the Internet Service Providers (ISPs), who are in unique possession of users' real identities. More precisely, copyright holders need the cooperation of so-called 'access providers', the companies supplying users with an Internet connection. Providers retain Internet traffic information for either legal or accounting reasons. Each IP is associated with a specific contract to supply a connection to the Internet. Therefore, ISPs can match IP addresses with their customers' contract information and discover users' real identities. This is why copyright holders need the ISPs to collaborate. However, some ISPs refused to cooperate, thus forcing copyright holders to turn to the courts to try to obtain orders to oblige providers to release user identities.

Although the tools used by plaintiffs vary according to the legal system in which they are operating, ${ }^{138}$ they can all be considered to be discovery tools. ${ }^{139}$ The ultimate goal of these devices is to provide the plaintiff with the information necessary for a lawsuit: information in the possession of a subject other than the defendants.

In the US system two different tools exist. The first is provided by $\S 512(\mathrm{~m})$ the Digital Millennium Copyright Act (DMCA), ${ }^{140}$ while the second is the so-called 'John Doe' process, based on the Federal Rule of Civil Procedure n. 45. The latter is equivalent to the device applied in the Canadian context, which relies on Rules 233 and 238 of the Federal Court Rules. In Italy the rule applied is that of art. 156bis of Legge 22 April 1941, n. 633, regulating diritto d'autore (copyright).

When asked to reveal their customers' information, providers raised concerns about user privacy and personal data protection. These concerns are at the heart of the conflict I wish to investigate in this book.

On one side we have the copyright holders, who are trying to enforce their rights, in compliance with the right to an effective remedy. On the other side stand the users whose activities have been traced and whose data have been collected without consent.

To give a better picture of my analysis of the conflict, further details are required. The clash of rights studied in this book is based on two

138 See Chapter 2, Section 6 for a detailed explanation.

139 The Italian system does not explicitly provide any of these tools. Nonetheless, an analysis of the tools provided for the enforcement of copyright reveals the similarities between these and the discovery tools existing in common law countries.

140 An Act of October 28, 1998, Pub. L. 105-304, 112 Stat. 2860. 
premises. First: to a greater or lesser extent the US, Canada and Italy all have regulations that hold file-sharing to be a copyright-infringing activity. One of the first objections that is often made to these lawsuits is that copyright has not actually been infringed by the users. For the purposes of my argument, I shall assume that copyright violation did, in fact, occur. ${ }^{141}$ The second assumption is that all three countries protect privacy, both physical and informational. It is well known that the approach taken by the US differs considerably from that of the EU, and, in turn, of Italy. The Canadian experience is very close to the European.

In the cases examined here, the plaintiffs were associations of copyright holders, and not copyright holders themselves. This means that the enforced rights were clearly and solely economic. ${ }^{142}$ There is reason to believe that this aspect was actually considered by some courts in their decisions, as will be demonstrated throughout this book. It is crucial to note, however, that if the uniquely economic nature of the rights had been more thoroughly considered, different decisions might have been reached. Indeed, if one considers copyright to be an 'economic' right and privacy to be a 'personality' right, the two should not be assigned equal value. ${ }^{143}$

With regard to privacy and personal data protection, it should first be noted that the service companies collected user data with neither the consent, nor even the knowledge, of the people concerned. The collected data were mainly IP addresses and traffic information, which leads to an initial question: are IP addresses personal data?

141 I shall nonetheless explain in Chapter 2 when and where the violation was actually present.

142 A different situation would be one where the rights enforced were 'moral rights'. Moral rights are recognized by the Berne Convention at art. 6bis. However, signatory states have implemented this provision differently. As is well known, European copyright also recognizes a 'moral right' of authors, which is a personality right that cannot be waived. The US does not recognize a moral right for any work of authorship; instead it has introduced specific provisions for some rights (for instance the Visual Artists Rights Act (VARA), Pub. L. 101-650, 104 Stat. 5132, December 1, 1990). Italian Legge 633/41 includes moral rights in arts. 20,21, 24, 142 and 143. A similar situation exists in Canada, as the famous Supreme Court decision in Théberge clearly stated (Théberge v. Galerie d'Art du Petit Champlain Inc [2002] 2 S.C.R. 336). Moral rights in Canada are provided by the Copyright Act, S. 14.1, S. 14.2, S. 17.1, and S. 17.2.

143 Cf. Tar Roma, Ord. 26.09.2014, no. 10020, according to which the Italian Constitution puts fundamental rights and economic liberties on two different levels, so that, in case of conflict, the latter should be sacrificed. 
To answer this question properly, I must first define what I mean by privacy in the context of this book. Unlike copyright, which is a legal concept, "[t]he term "privacy" is an umbrella term, referring to a wide and disparate group of related things. The use of such a broad term is helpful in some contexts yet quite unhelpful in others.' 144

Since its first appearance in Warren and Brandeis' article, ${ }^{145}$ scholars have been trying to give a precise definition of the 'right to privacy'. ${ }^{146}$ It has been significantly claimed that "privacy is so hopelessly diffuse as to be virtually indistinguishable from the related concepts of liberty, autonomy and freedom'. ${ }^{147}$ So many different attempts to define privacy have been made that it is pointless to even try to summarize them here, ${ }^{148}$ instead I would prefer just to quote an existing definition that should be kept in mind while reading this book. Privacy can be thought of 'as the ability of an individual to exercise control over how his/her personal information is collected, used or disclosed by third parties'. ${ }^{149}$ This definition is very close to the one regarding the 'protection of personal data', which is at the core of my research. Indeed, the collection and use of an individual's personal information can have a great impact on their privacy; this puts privacy at the heart of personal data protection ${ }^{150}$ and is very probably why the two concepts often overlap. I welcome this

144 Daniel J Solove, 'A Taxonomy of Privacy' [2006] University of Pennsylvania Law Review 477, 485.

145 Samuel D Warren and Louis Brandeis, 'The Right to Privacy' [1890] 4 Harvard Law Review 193.

146 See the ironic words of Helen Nissenbaum, Privacy in Context. Technology, Policy, and the Integrity of Social Life (Stanford University Press 2010) 2-3. For useful insights, see Daniel J Solove, Understanding Privacy (Harvard University Press 2008) 1-39.

147 Colin J Bennett, Regulating Privacy. Data Protection and Public Policy in Europe and the United States (Cornell University Press 1992) 26.

148 For a summary and brief explanation of the 'leading definitions' of privacy, see Colin H H McNairn and Alexander K Scott, Privacy Law in Canada (Butterworths 2001) 4ff; see also Peter Burns, 'The Law and Privacy: The Canadian Experience' [1976] Reveu du Barreau Canadien/Canadian Bar Review 1, 4-12. Flaherty lists a number of information-related interests protected by the right to privacy: see David H Flaherty, Protecting Privacy in Surveillance Societies (North Carolina University Press 1992) 8, table 1.

149 Mark S Hayes, 'The Impact of Privacy on Intellectual Property in Canada' [2006] Intellectual Property Journal 67, 68.

150 Margaret Ann Wilkinson, 'Battleground Between New and Old Orders: Control Conflicts Between Copyright and Personal Data Protection' in Ysolde Gendreau (ed), An Emerging Intellectual Property Paradigm: Perspectives from Canada (Edward Elgar Publishing 2008) 227, 244-246, sic passim. 
overlap, which is often proposed by laws, as well as by judges. ${ }^{151}$ The term 'information privacy', which can be seen as a crasis of the two concepts of physical privacy and personal data protection, also testifies to this overlap. ${ }^{152}$

Another interesting definition which could be applied in this work was given by the Australian Privacy Commissioner: '[i]nformation privacy concerns the handling of "personal information", that is, information about a particular person or information that can be used to identify a particular person'. ${ }^{153}$ The definition is also very close to Alan Westin's, that information privacy is 'the claim of individuals, groups or institutions to determine for themselves when, how and to what extent information about them is communicated to others'. ${ }^{154}$ The manner in which personal information is spread can represent an individual's way of being, and is thus related to their personal identity. ${ }^{155}$

This work does not necessarily need to rely on a specific definition of privacy. It is, however, important that we share a general understanding of the concept, particularly with respect to information. For the sake of clarity, I will adopt the definition given above - and which best fits my present purpose - that privacy is 'the ability of an individual to exercise control over how his/her personal information is collected, used or disclosed by third parties'.156 The terms privacy/information privacy/ personal data protection will be used interchangeably, although I am conscious that there are, or may in some circumstances be, differences between them. These differences are sometimes the result of the differences in the conception and perception of this right. ${ }^{157}$ As will be seen

151 Juliane Kokott and Christoph Sobotta, 'The Distinction Between Privacy and Data Protection in the Jurisprudence of the CJEU and the ECtHR' [2013] International Data Privacy Law 222.

152 See Lee A Bygrave, 'Privacy and Data Protection in an International Perspective' [2010] Scandinavian Studies in Law 165, 168-171.

153 'What Is Information Privacy And Why Do We Need To Protect It?' in Australian Privacy Commissioner, Information Privacy in Australia: A National Scheme for Fair Information Practices in the Private Sector, August 1997 $<$ http://www2.austlii.edu.au/itlaw/national_scheme/national-PART.html> accessed 12 August 2017.

154 Cf. Alan F Westin, Privacy and Freedom (Atheneum 1967) 7.

155 Giovanni Buttarelli, Banche dati e tutela della riservatezza. La privacy nella società dell'informazione (Giuffrè 1997) 95.

156 Hayes (n 149) 68.

157 Lee A Bygrave, 'International Agreements to Protect Personal Data' in James B Rule and Graham Greenleaf (eds), Global Privacy Protection: The First Generation (Edward Elgar Publishing 2008) 15, 15-17. 
later, the US usually uses the term 'privacy', while the current European and Canadian frameworks revolve around the concept of 'personal data'.

Having clarified how the term 'information privacy' will be used in this work, I will now turn to IP addresses. In order to establish whether or not IP addresses fit into the definition of personal data, we must define them. So, an IP address is a number assigned to a device connected to a network that applies what is called 'Internet Protocol' communication. The number works both as an interface identification and as a locating address. Possession of a user's IP address enables detection of where the device with that number is; the IP address identifies the exact location of a given node on the Internet. At the consumer/user level, IP addresses are assigned by the access provider according to a specific method. IP addresses can be assigned either dynamically or statically. Dynamic assignation - the most common - means that each time a device connects to the network, the ISP assigns it a new number. Each ISP usually has a given number of IP addresses that it can assign to its customers and it may therefore suit an ISP, when one device disconnects from the system, to reassign its dynamic IP address to another device. Static IP numbers, in contrast, retain the same configuration, with the address being assigned 'once and for all'. ${ }^{158}$

Tracking and registering IP numbers enables whoever is carrying out the operation to know when users are doing what. So if, for example, I like to stream certain movies at night, tracking my IP will reveal what I am watching and at what time. This may be information that I am happy for others to have. It may, however, be information that I want to keep very secret. In either case, it is information about me. From this point of view, an IP constitutes 'personal data' and its tracking and recording by third parties is therefore a 'processing' of personal data.

IP addresses have been considered personal data by courts and by privacy authorities, although this depends on the legislation in place and, in particular, on how exactly 'personal data' is defined. For instance, the Assistant Privacy Commissioner of Canada held that IP addresses were personal information since they could be combined with the records of ISPs to identify users. The Canadian Personal Information Protection and Electronic Documents Act (PIPEDA), in fact, defines personal information as 'information about an identifiable individual' (Section 2(1)). Since an IP number can be associated to a specific person, it should be

158 See Entry: Internet Address in Collin (n 131). 
considered to be personal data. ${ }^{159}$ The same interpretation was given by the Article 29 Data Protection Working Party, ${ }^{160}$ according to which 'IP addresses attributed to Internet users are personal data and are protected by EU Directives 95/46 and 97/66'. ${ }^{161}$ Indeed, the definition of personal data according to European Directive 95/46 comprises 'any information relating to an identified or identifiable natural person' ${ }^{162}$

The European Data Protection Supervisor also considers IP addresses to be personal data under Directive 95/46. The Supervisor stated that, since "an IP address serves as an identification number which allows finding out the name of the subscriber to whom such IP address has been assigned', 'it is only possible to conclude that IP addresses and the information about the activities linked to such addresses constitutes

159 See PIPEDA Case Summaries n. 25/2001 - A Broadcaster Accused of Collecting Personal Information via Web Site <www.priv.gc.ca/en/opc-actionsand-decisions/investigations/investigations-into-businesses/2001/pipeda-2001-025/> accessed 10 February 2017; n. 2005/315 - Web-centred company's safeguards and handling of access request and privacy complaint questioned <www.priv.gc. ca/en/opc-actions-and-decisions/investigations/investigations-into-businesses/ 2005/pipeda-2005-315/> accessed 10 February 2017; n. 2005/319 - ISP's anti-spam measures questioned <www.priv.gc.ca/en/opc-actions-and-decisions/ investigations/investigations-into-businesses/2005/pipeda-2005-319/> accessed 10 February 2017: 'an IP address can be considered personal information if it can be associated with an identifiable individual ... For the purposes of this complaint, which involved the sending of e-mail by the complainant, the Assistant Commissioner accepted that the originating IP address identified the complainant and was therefore his personal information, as per section 2' of PIPEDA.

160 Art. 29 Working Party is so called because it was introduced by art. 29 of Directive 95/46/EC of the European Parliament and of the Council of 24 October 1995 on the protection of individuals with regard to the processing of personal data and on the free movement of such data. See Chapter 3, Section 3.2 for more information.

161 Opinion 2/2002 on the use of unique identifiers in telecommunication terminal equipment: the example of IPv6, adopted 30 May 2002, at $3<\mathrm{http}: / / \mathrm{ec}$. europa.eu/justice/data-protection/article-29/documentation/opinion-recommendation/ files/2002/wp58_en.pdf>. Consider also Opinion 4/2007 on the concept of personal data, adopted 20 June 2007, at $16<\mathrm{http}: / /$ ec.europa.eu/justice/dataprotection/article-29/documentation/opinion-recommendation/files/2007/wp136_ en.pdf $>$ and Opinion 1/2008 on data protection issues related to search engines, adopted 4 April 2008, at $8<\mathrm{http} / / /$ ec.europa.eu/justice/data-protection/article-29/ documentation/opinion-recommendation/files/2008/wp148_en.pdf $>$ all accessed 10 February 2017.

162 Emphasis added. 
personal data'. ${ }^{163}$ The CJEU has also considered IP addresses to be personal information. ${ }^{164}$

Inevitably, opinions on the qualification of IP numbers as personal data vary, among both academics and courts. Some academics, for instance, hold that an IP address does not identify a person, because it only reveals the device from which specific content comes. Therefore, the IP number itself cannot lead to the identification of a person: only the subsequent matching of that IP number with the personal information held by the ISP allows the identity of the user to be established. This would mean, in turn, that IP addresses were only 'partial' personal data. ${ }^{165}$

A recent decision by the CJEU provides another example of this interpretative ambiguity. In 2014 the Bundesgerichtshof (Federal Court of Justice of Germany) filed a reference for a preliminary ruling in order to establish whether an IP addresses could be considered personal data per se when only a third person has further information that would enable the user to be identified. The opinion of the Advocate General in the case was that "a dynamic IP address ... constitutes ... "personal data", to the extent that an Internet service provider has other additional data which, when linked to the dynamic IP address, facilitates identification of the user'. ${ }^{166}$ The Court itself reached a very similar conclusion, stating that IP addresses are personal data when the provider has additional information and the legal means with which to identify the subject. ${ }^{167}$

In addition to the above, it is important to be aware that IP addresses can give misleading information, especially in contexts such as the one here considered. As mentioned, dynamic IP numbers can be assigned to different people at different times. A subject may be sued because her IP number is linked to an infringing activity, even though she had nothing to

163 EDPS Opinion, 22 February 2010, OJ 2010/C 147/1, Opinion of the European Data Protection Supervisor on the current negotiations by the EU of an Anti-Counterfeiting Trade Agreement (ACTA).

164 See the CJEU's decision in Case C-70/10 Scarlet Extended SA v. SABAM [2011] ECR I-11959, para 26.

165 Pieremilio Sammarco, 'Alla ricerca del giusto equilibrio da parte della Corte di Giustizia UE nel confronto tra diritti fondamentali nei casi di impiego di sistemi tecnici di filtraggio' [2012] Diritto dell'informazione e dell'informatica 297. For a very similar approach, see also Fanny Coudert and Evi Werkers, 'In the Aftermath of the Promusicae Case: How to Strike the Balance?' [2008] International Journal of Law and Information Technology 50, 57ff, spec. 60.

166 Case C-582/14 Patrick Breyer v. Bundesrepublik Deutschland [2016] ECLI:EU:C:2016:339, Opinion of AG Campus Sanchez-Bordona, para 106.

167 Case C-582/14 Patrick Breyer v. Bundesrepublik Deutschland [2016] ECLI:EU:C:2016:77914, paras 49 and 65. 
do with the actual infringement. Furthermore, and most importantly, an IP address only identifies the machine that is linked to it, and not the person behind the screen when the infringing activity occurred. Some courts have raised these concerns, in cases such as the ones we are examining here. ${ }^{168}$

Based on these premises, IP numbers can be considered personal information. The nature of the conflict should now be obvious, and likewise the task that judges were (and are) obliged to carry out, that of balancing the conflict between copyright and informational privacy.

While the US, Canadian and Italian systems differ significantly in many ways, judges in all three jurisdictions have found themselves struggling to understand which right should prevail. As I will go on to discuss, this is partly due to the ambiguity of the above-mentioned provisions. It is also connected to the fact that the preservation of one of the rights is impossible without detriment to the other: if copyright is to be enforced, users' personal data must be disclosed and vice versa: the preservation of users' personal information means that copyright cannot be enforced.

It is true that the theories mentioned in the previous section always deal with fundamental or constitutional rights, which copyright and information privacy are not necessarily considered to be. However, the US, Canada and Italy all consider privacy (including informational privacy), to be a constitutional right. Even though none of the countries specifically mentions privacy in its fundamental Charter, they have all developed consistent case law that now permits the inclusion of privacy within constitutionally recognized rights. ${ }^{169}$ In addition, some international and supranational charters, such as the European Convention on Human Rights (art. 8) and the European Charter of Fundamental Rights and Freedoms (arts. 7 and 8), consider privacy to be a fundamental right. Moreover, privacy is mentioned among the rights protected by art. 12 of the Universal Declaration of Human Rights.

The characterization of copyright as a constitutional, fundamental right is more questionable. None of the three systems explicitly includes copyright in its Constitution. Nonetheless, intellectual property (hence,

168 '[T]his Court's concerns about the conduct of this litigation going forward, particularly in light of the serious questions about plaintiffs' ability to properly identify defendants based solely upon their IP addresses', Malibu Media, LLC v. John Doe, CV 12-1147 (JS) (GRB) $5<$ http://beckermanlegal.com/ Lawyer_Copyright_Internet_Law/inrebittorrent_120731Order.pdf> accessed 10 February 2017.

169 See Chapter 3, Section 2. 
copyright) is commonly traced back to the right to property, which is usually recognized as both a constitutional and a fundamental right. ${ }^{170}$ Furthermore, copyright (intellectual property) is mentioned in art. 17 of the European Charter of Fundamental Rights and Freedoms. And so, although there is no unanimous consensus on the qualification of either right as 'fundamental' or even 'constitutional', for the purpose of this book we can accept that they have both been treated as such.

Both copyright and privacy originated, and continue to exist, as 'rights in balance'. As we will see in the next chapter, copyright regulation always contains certain limits to the copyright holder's rights. From its inception, copyright has provided a means for balancing the interests of author and public. Modern copyright legislation is the result of a checks-and-balances process in which the different rights of different stakeholders need to be preserved. A variety of measures, such as the choice of copyrightable works, the duration of copyright, and the exceptions and limitations applicable, (should) enable this balance to be achieved.

The same argument applies to privacy. The right to privacy has always been conceived as a limit to the freedom of speech; the notion of privacy arose as a counterbalance to the invasive thrust of journalism made possible by the introduction of new technologies. ${ }^{171}$ This characteristic of the right to privacy persists, as the fact that privacy is more and more often juxtaposed with surveillance and national security demonstrates. The whole history of privacy and personal data protection is built on the concept of balancing ${ }^{172}$ and so it is no surprise that information privacy has also collided with copyright enforcement.

The need to find equilibrium is an intrinsic part of modern society. On the one hand lie individual interests; on the other, public and/or collective ones. In democratic societies, the task of striking a correct balance is usually delegated to lawmakers and, in a second phase, to interpreters.

This book is an attempt to further investigate the role of interpreters judges, in this instance - in the difficult task of rights balancing.

170 See Chapter 2, Section 2.

171 Here I am again referring to Warren and Brandeis (n 145). See also the book by M Tunick, Balancing Privacy and Free Speech. Unwanted Attention in the Age of Social Media (Routledge 2015). See also the words of the 'Soraya Case' by the Italian Corte di Cassazione: Cass. civ., 27.5.1975, n. 2129 in Foro it., 1976, I, 2895.

172 See Chapter 3, Section 2. 


\section{A DIFFERENT HYPOTHESIS: CONCEPTUAL BALANCING?}

Balancing - in all forms - is now a fact; it originated a century ago in the minds of academics, was later taken up by courts, and is currently widespread in a number of different areas of law. It is therefore here to stay.

Although now extensively adopted as judicial practice, ${ }^{173}$ balancing does not have the same meaning in all jurisdictions. On the contrary, in spite of what seems to be a 'common language', approaches may differ greatly. ${ }^{174}$ However, many scholars believe that the approaches being taken on either side of the Atlantic are becoming increasingly more alike. ${ }^{175}$ That said, even if the approaches taken were one day to become identical, the courts' decisions would not necessarily follow suit. Balancing depends on so many different factors that it will probably never have identical procedures, or results, in any two or more countries.

As indicated above, balancing has mainly been adopted by Supreme and Constitutional Courts when they have had to decide on a statute's constitutionality. In this section, and throughout the entire book, I shall maintain and demonstrate that balancing has, in fact, been applied by all kinds of judge, whenever they have found themselves in certain situations. The aim of the 'lower courts' - courts other than the Supreme or Constitutional - in engaging in balancing is different from that of the 'higher courts'. This is especially true when a Supreme Court engages in a 'judicial review', i.e. decides on the constitutionality of a particular norm. Such decisions clearly have a much greater effect than any lower court judgment and can hypothetically influence an indefinite number of lawsuits. This is the case of the Italian Corte costituzionale, which only decides on the constitutionality of norms: it has no power as a Supreme Court in lawsuits between private parties; this latter power is attributed to the Corte di cassazione. Hence, a decision adopted by the Italian Constitutional Court might not be the 'final word' in a lawsuit in which a particular constitutional challenge has arisen. The role and power of the

\footnotetext{
173 Stone Sweet and Mathews (n 11) 74.

174 Jacco Bomhoff, 'Balancing, the Global and the Local: Judicial Balancing as a Problematic Topic in Comparative (Constitutional) Law' [2008] Hastings International \& Comparative Law Review 555, 560ff.

175 Barak, 'Proportionality (2)' (n 18) 754. See also the work of Stone Sweet and Mathews (n 11).
} 
Corte costituzionale is thus absolutely different from those of all the other Italian courts. ${ }^{176}$

Leaving the Italian case aside, however, an obvious remark can be made: lower courts need to balance rights in order to achieve concrete ends - to allow the plaintiff to win and the defendant to lose, or vice versa.

The interpretation of constitutional rights provides lower courts with possible solutions in cases where norms do not supply incontrovertible directives. ${ }^{177}$ Balancing thus becomes the tool by which judges reach a concrete decision; the instrument that allows them to overcome a stalemate, ${ }^{178}$ going beyond "the limitations of "law" in dealing with difficult cases'. ${ }^{179}$ Balancing is the method which, as I shall later explain, not only enables the actual norm to be applied, but also, crucially, draws attention to the whole concept of conflicting rights.

But when do lower courts actually need to balance conflicting rights?

Even though lower courts may want to - and do - apply the tool of balancing in a number of different circumstances, my understanding is that they find themselves obliged to balance conflicting rights when the following two factors come into play simultaneously: the colliding rights are considered to be of the same 'rank' - i.e. constitutional or fundamental rights - within the legal system in which the judge is operating; 180 and the norms which have precipitated the conflict provide no clear indication of how it might be resolved. ${ }^{181}$

With regard to the first requirement, the previous section illustrated how both copyright and privacy (including information privacy) can be traced back to countries' Constitutions. Indeed, in all three of the systems under consideration the interpretations of the courts, including the Supreme Courts, testify to the relevance and importance of both rights,

176 Bin (n 15) 120ff.

177 Gino Scaccia, 'Il bilanciamento degli interessi in materia di proprietà intellettuale' [2005] AIDA - Annali Italiani Diritto D’Autore 198, 198. The use of constitutional rights by lower courts to reach solutions in the case before them is a result of the 'constitutionalization' of private law: Pino, 'Conflitto e bilanciamento' (n 26) 7-9.

178 Contra: Zucca (n 10) 27.

179 Bomhoff, 'Balancing, the Global and the Local' (n 174) 582.

180 It should be noted, however, that the way that conflicts arise depends on the way rights are interpreted: Zucca (n 10) 27.

181 Meaning when 'the issue to be decided ... seems to be subsumable at the same time into two or more norms' and there is 'no precise and unambiguous rule to be applied' to the case: Pino, 'Conflitto e bilanciamento' (n 26) 2 [my translation]. 
and their fundamental, constitutional nature. This interpretation is also the result of the 'constitutionalization' of both rights at a supranational level, especially in the European context.

The analysis conducted in the next two chapters clearly demonstrates that the trend towards acknowledging both copyright and privacy as fundamental rights started many decades ago and is still ongoing. This, however, does not mean that one of the two rights cannot be accorded greater importance than the other within the system as a whole. Indeed and this point lies at the heart of the book, and will be returned to later this has been the basis of all of the decisions taken by judges when they have found themselves facing the conflict between privacy and copyright.

The second requirement, as stated above, refers to norms which create conflicts which they then leave open. For instance, a norm can easily solve a conflict if it includes a phrase such as "notwithstanding the provision ...', clearly asserting that the protection of a right has to be safeguarded, even to the detriment of another/others. Conflicts can also be avoided by including specific exceptions within the norm itself. ${ }^{182}$

As will emerge from the case studies, the fact that the norms lacked clarity led judges into an impasse that could be - and in fact was resolved only by weighing the interests at stake. ${ }^{183}$ In cases where each litigant's legal interest is legitimate, but the court must nonetheless take a decision, ${ }^{184}$ balancing becomes a necessity: it represents an empirical process through which judges can resolve a matter which would otherwise be irresolvable. The ambiguity resulting from the lack of a prevalent right - which may sometimes be intended by lawmakers, to give judges some leeway - means that judges have the opportunity, indeed the duty, to read the particular case in the light of the entire conception of each conflicting right.

Regardless of the methodological approach to balancing, which may differ from system to system, and even within a given system, judges who find themselves having to decide which right should prevail tend to consider what I have called the 'conception' of the conflicting rights. By 'conception' of a given right I mean the attitude of a legal system to that right. Conception emerges out of the organic whole of laws and policies

\footnotetext{
182 Pino, 'Conflitto e bilanciamento' (n 26) 16.

183 Ansgar Ohly, 'European Fundamental Rights and Intellectual Property' in Ansgar Ohly and Justine Pila (eds), The Europeanization of Intellectual Property Law (OUP 2013) 145, 156.

184 Stone Sweet (n 6) 11.
} 
relating to a specific institution. It is both the essence of all regulations on a right and also the key to a systematic reading of the laws affecting that right.

This idea may not be immediately obvious; it should, however, be clarified by the analyses of copyright and (information) privacy found in Chapters 2 and 3 respectively. To begin with, the following example may prove helpful: Freedom of speech is generally recognized as a value of huge significance in the American system; even when it conflicts with other fundamental and constitutional rights it often prevails. ${ }^{185}$ In my analysis of 'conception' this would mean that the 'conception' of freedom of speech in the US is particularly strong: the right pervades the entire legal system.

Although clearly not all rights or freedoms enjoy such a privileged position, some are regularly given pre-eminence over others. Essentially, the pre-eminence of a right is the product of a systematic interpretation of all the rules that govern it. The pre-eminence and strength of one right, and the inferiority or weakness of another, testify to the conception that a given system allocates to each right.

In some instances, a right is given predominance over others as a matter of law, this occurs (as already mentioned) when a law clearly states that one right must be preserved to the detriment of another. Another instance is when judges decide that one right should prevail over another: in such cases pre-eminence is not conferred by one specific regulation but is the by-product of a system of law, which, taken as a whole, portrays one right or freedom as more important than others.

This means that a situation in which two rights collide can always be resolved by looking at the system in its entirety, which entails looking at the systematic structure of the two rights. A further implication is that interpretation has to begin by examining the constitutional dimension of a right and carefully considering the way in which that right is regulated by the legal system. The conception of a given right is the sum of a number of indicators that can be gathered from any regulatory tool that involves and affects that right. A right's conception can be deduced by

185 Paul Bernal, 'The EU, the US and Right to be Forgotten' in Serge Gutwirth, Ronald Leenes and Paul de Hert (eds), Reloading Data Protection. Multidisciplinary Insights and Contemporary Challenges (Springer Verlag 2014) 61, 69-70; Stone Sweet and Mathews (n 11) 164. This was called 'a rule of priority' by Zucca (n 10) 36-37. See, more generally, Frederick Schauer, 'The Exceptional First Amendment' in Michael Ignatieff (ed), American Exceptionalism and Human Rights (Princeton University Press 2005) 29. 
analysing a wide range of legal tools, including the Constitution and its interpretation by courts, and governmental acts, at both national and local level. The conception of a right can also be derived by examining the framing and wording of laws and regulatory tools in general. As already mentioned, a simple statement that a particular right shall prevail demonstrates that a certain degree of importance is attached to that right: if only one right is mentioned, then it is clearly considered to be highly relevant or, at least, of higher relevance than the other rights involved.

Another signal of the value placed on a right is the way in which it is regulated: if lawmakers assume the burden of regulating most - or even any - aspects of the situations in which a right is at stake, that right is clearly considered to be of particular prominence in the system concerned. A virtuous circle then develops: the more a right is regulated, the greater the importance attached to and acquired by it becomes. Judges place ever higher value on the right and its importance consequently increases, and so on. Obviously, the opposite is also true: a right which is considered of lesser importance than others may be marginalized.

This is the process by which judicial reasoning is influenced by the conception of a given right, especially when the norms to be applied are not clear, as in the cases analysed in this book. Chapters 2 and 3 contain my analysis of the relevant legislation, revealing specific pictures for the two conflicting rights in each of the three countries. The decisions adopted by the courts of each country reflect - in the majority of cases the conception of copyright and information privacy held by that country's legal system. I shall therefore maintain that when two rights have to be balanced against one another, the entire conception of each right weighs either in favour of or against it; the conception of the two rights is the ground for judicial rulings.

As I will demonstrate in Chapter 3, privacy is more highly valued in the Euro-Italian and Canadian contexts than it is in the American, where it is regarded as just one among many rights. Therefore, even though the approach taken by the three jurisdictions to copyright is similar (and has been getting closer), only in the US does the enforcement of copyright usually prevail over information privacy. I understand these outcomes as the result of the different conceptions of privacy and copyright in the three countries: this is what I call conceptual balancing.

Conceptual balancing can be summarized as follows: when two constitutional rights collide and there are no clear rules by which to define the dispute, courts approach the conflict by balancing the two rights. The solution is reached by considering the conception of both rights, i.e. their regulatory structure. Prevalence is given to the right to which the legal system as a whole attaches more importance. 
While normally balancing is a technique applied by Supreme and Constitutional Courts, my aim is to show that, in fact, the 'lower courts' also apply the balancing method.

Of course, judges may be influenced by a number of factors, when weighing conflicting rights, and balancing can, on occasion, become a door through which cultural values enter into judicial decisions. ${ }^{186}$ In fact, the entire conception of a right may be - and usually is - a by-product of the cultural understanding of that right. Policies may endorse and enhance the socio-cultural context in which they develop; policies, in turn, are embodied in judicial decisions. ${ }^{187}$

The interpretation of any right depends on the circumstances of the case in question, as well as on when and where the decision is taken. As mentioned earlier, balancing is influenced by a number of factors inherent within each legal system: the solution applied in one country may never be applied in another. Societal and cultural values are key factors in this regard, heavily influencing the cultural model and expectations of justice within the society in which the decision is delivered. ${ }^{188}$ It has also been argued that balancing can have either an 'elementary form' or a 'sophisticated version': the latter also weighs societal interests beyond the actual conflict at stake. ${ }^{189}$

Many of the factors that impact upon judicial decision making are very hard to detect, just as 'gravity' is, when tangible objects are weighed on a set of scales. ${ }^{190}$ From this perspective, balancing should neither be considered as a scientific method of weighing, nor as the description of such a method; rather, it is a metaphor for a multi-factorial decision, a decision taken by considering elements that go beyond simple logic or hermeneutical analysis of the text of the law. ${ }^{191}$

While there is a lot of scepticism about the very concept of balancing, ${ }^{192}$ it may, in fact, be the only method by which all the values at stake in today's societies can be taken into account. Balancing should be

186 Social perception is also key in accepting a specific decision and its rationale; this is especially true with respect to constitutional review: Alexy, 'Balancing' (n 60) 579-580.

187 I have argued this more thoroughly elsewhere: Giovanella (n 37).

188 Scaccia (n 23) 3964; Barak, 'Proportionality and Principled Balancing' (n 40) 7-10.

189 McFadden (n 1) 586.

190 Luizzi (n 11) 388-390.

191 Scaccia (n 23) 3986.

192 In addition to the works already cited, see Xavier Groussot, 'Rock the KaZaA: Another Clash of Fundamental Rights' [2008] Common Market Law Review 1745, 1761. 
conceived of as a way of putting every factor in its just position. This is especially true when balancing is applied by 'lower courts', as in the cases here analysed. Technological development may allow new types of copyright infringement and privacy violation but balancing should be seen as a tool that enables judges to make proper decisions on the basis of each actual case.

As a final remark, I would like to point out once again that this work is based on case studies and thus only examines a limited range of lawsuits, namely those involving copyright and information privacy. Nonetheless, the methodology employed, as well as the overall idea of 'conceptual balancing', can be applied in any case where two (or more) rights collide. The analysis conducted in this book can serve as an example of a wider problem and may be considered a prototype, or an emblematic example, of clashes between two rights. Conceptual balancing should be seen as a new categorization of a not-so-new approach to judicial reasoning. My analysis is not intended to prescribe any particular role for the judges involved, and even less to explain how they should decide cases. It is just another, humble, contribution to the analysis of judicial reasoning. 